\title{
最近における石油製品の性能評価方法についで
}

古屋和 彥**

\section{1.緒 ‥}

$\therefore$ 石油製品と、Uて灯油的最初炕商品化されて以来，蒸 気機関用シリシダー油が鉒残油から得られ，重油の水

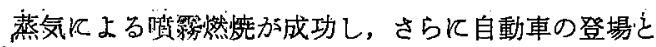

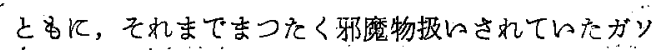
リンが広く使用されるよらイなり，続いてディーゼル 機関が重酒を使用するごとによつてその革命的価値を 発揮し, 一方, 西的先機械類は石油製品をる潤滑油 の使用によつて近代交化の華となつた，かくして石油 製品はきわめて多種多㥞にわたり，社会文化の隅沉 まで影響を及䄈すに至り，品質面に対する要求す年を 追つて苛酷になり，それに伴つて製造法法進歩し，規 格前びて試験法注改良を重ねられて来を。元来, 規格

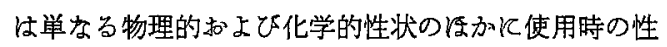
能をす勘案して作られねね゙ならない. 前者は色相, 比 重, 粘度, 引火点, 流動点, 酸価, 炭化分なとであり， 後者は発熱量, オクタン価, セタン洒, 絶緑洏力, 粘 度, 粘度指数, 抗乳化度, 酸化安定性, 潤滑性, 防水 能, 腐蝕防止能, 消泡性である。この上う使用時の 各性質は用途別に応じてその規格が制定され，その試 験法が確立されるべをであるが，実際には製造時に和 け当製品の均一を保持するを助の規格も少なくないし，

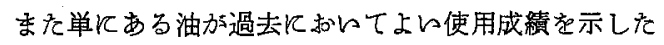
ために，その油の性状を基乍にした特別の重要な意義 があるとも思えないような規格打よと試験法が制定さ れているとともある。

さて，石油製品の評価法に次の 3 段階がある.

（1）用途加ら考充て必要な，特殊の，個々の性質 を把握し，その必要度を決定する。

（2）前記各特殊性質の評研法を決定する.

（3）実用実験によつて，乙の特性が满足されるか 否加を検討する。

これが石油製品を製造し，股壳し，購入するえめの 評価方法の根本的な考光方であり，品質を磪保するた めに規格を制定する基本的な考允方である。との考充 方湍を発して近時石油製品の使用時に和ける害用性 能の判定方重要視されるに至り, 各種試験方法が提案

* 缐穆受付 昭和31年 9 月13日

***整石被㧣式会社

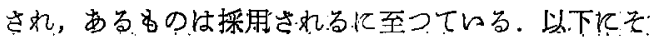
の和すなっの列举する。

\section{2. 石油製品の実用性能誌験法}

(i) カ゚ソリンのロードオタタン価 従来のオク. タン価はイッオクタンとノルマルヘプタンを標準にし 特定の試験用機関で，特定の条件下飞和方相対的

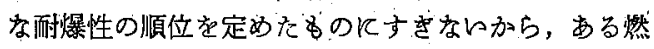
料のモーター法，あるいはリサーチ法によるオクタン 価加同一であつても，実際の走行にあたつては，自動 車の速度その他の運転条件により，ノッングの起る 傾向愇つてくる. したがつて, 単に実験室的方法に よつて求めたオクタン価だけで，ガソリンの品質をう

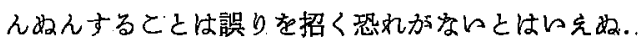
それ师え road test を行い実用的なオクタン洒を貺定 することが行われ，接触改質ガソリン，接触分解ガり リンなとの特慛も明らかれされるに至つた。

現在, とのロードオクタン価の測定に最も一般に唐 ウられているのは modified uniontown 法 (CRC Designation F-28) 和上び modified borderline 法 (CRC Designation F-27) である。次炕との測定法を 簡単飞記载する.

（a）Modified union town 法 燃料として標 準燃料を用々, top gear $て ゙$ full throttle acceleration 行つて生するノック音が trace の強さを越え妨よう な basic spark timing を決定する。同様なことを各、 オクタン価の標準燃料について行えば，第 1 図のよう

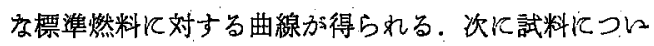

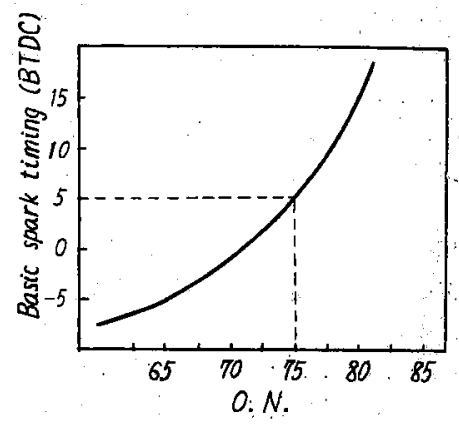

第1 図 Basic spark timing と load octane number との関倸図 
て同様な測定を行つて, basic spark timing 決定す れば第1図よりそのロードオクタン価を知るととがで

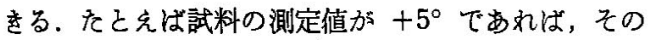
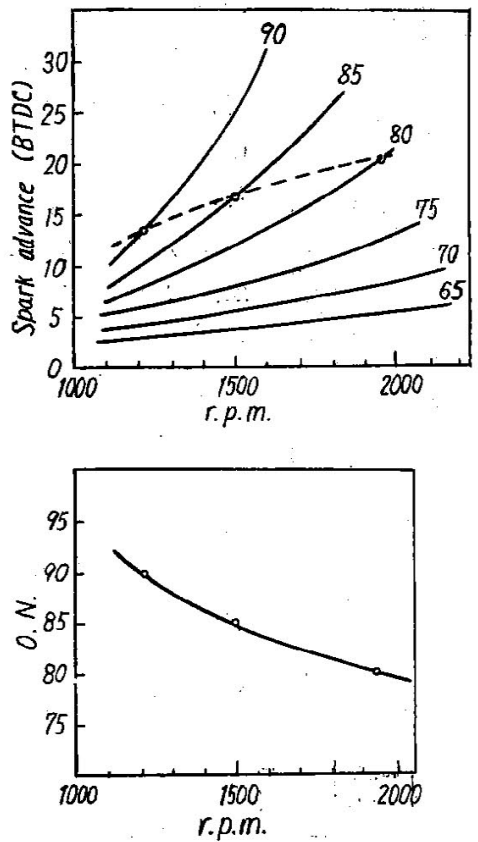

第2図 Octane number とエンジン回転数さの 関係図 (modified borderline curve)

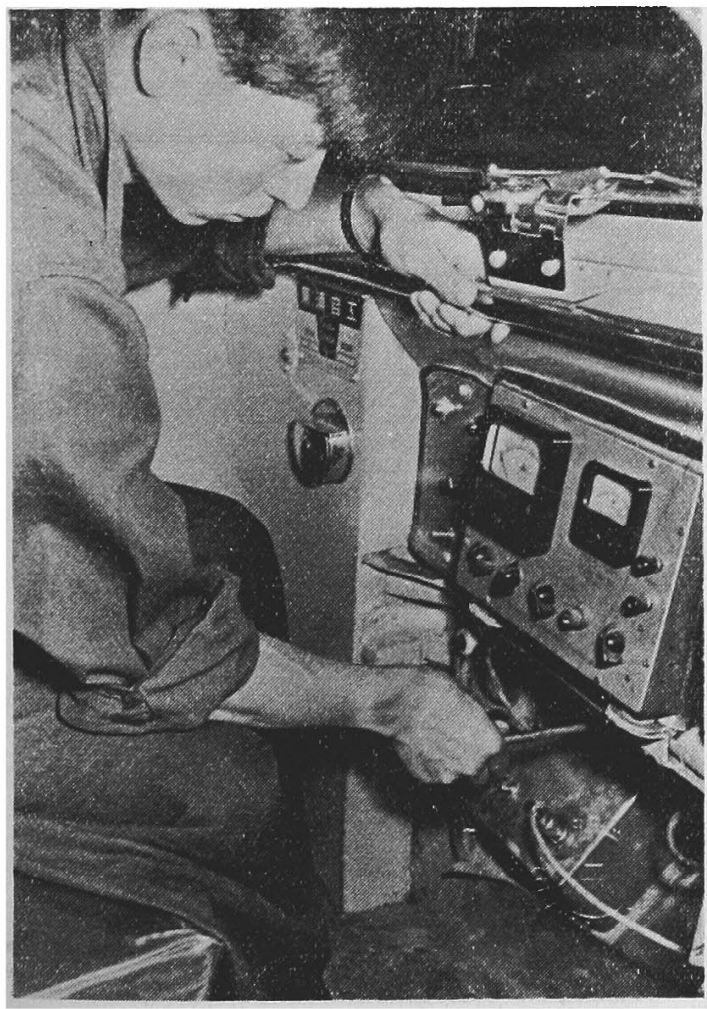

写真 1.ロードオクタン洒測定計器 modified uniontown ロードオクタン価は75である. 本法は普通の点火装置の車で測定できるととを特徽と するが,オクタン価とエンシンン回転数との関倸は得ら れない.

(b) Modified borderline 法 top gear 氏お2 ける full throttle acceleration 中伤点火角常に trace knock が起るように変化させて点火角度とメン シン回転数との値を測定する方法でる。このような 測定を各オクタン洒の標準燃料につ々て行允ば第 2 図 のような曲線が得られる。次に試料について測定を行 つて点線のような曲線を得たとす㣗ば，乙れと標準然 料による曲線との交点から，オクタン価とエンジン回 転数の関係を示す曲線加得られる。乙れが試料の modified borderline curve である。この測定法によ

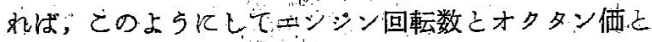
の関係が得られ，之の試料の走行性能が明瞭注园示

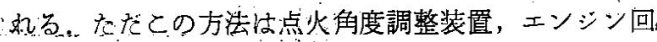
転計，および点火角度指示計を㖓備与る必要がある。

写真1江慗社中央研究所所有のテス、トカーに装備した ロードオクタン価測定計器である（手で操作している ヘンドルが点火角度調整装置であり，その上の計器が ハックメーターである)

(ii) エンジン油のエンジンテスト エンジン油 第 1 表 エンシン油の試験項目と試験条件

\begin{tabular}{|c|c|c|c|c|}
\hline \multicolumn{2}{|c|}{ チンシンン名称。 } & \multirow{3}{*}{\multicolumn{2}{|c|}{$\begin{array}{l}\text { ローソン } \mathrm{H}-2 \\
\text { L型側丼式学気候 } \\
2^{5} / \mathrm{s}^{\prime \prime} \times 2^{3} / \mathrm{A}^{\prime \prime}\end{array}$}} & キャタビラ $-1-\mathrm{A}$ \\
\hline \multirow{2}{*}{\multicolumn{2}{|c|}{$\begin{array}{l}\text { 䍿 } \\
\text { 内佳 } \times \text { 行瘦 }\end{array}$}} & & & 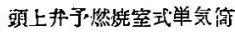 \\
\hline & & & & $5^{3 / 4}+8^{\prime \prime}$ \\
\hline \multicolumn{2}{|c|}{ 榣排気量 } & \multicolumn{2}{|l|}{$244 c c$} & $3400 \mathrm{cc}$ \\
\hline \multicolumn{2}{|c|}{ E 縮 比 } & \multicolumn{2}{|l|}{$5 \cdot 0$} & $15 \cdot 5$ \\
\hline \multirow{3}{*}{\multicolumn{2}{|c|}{ 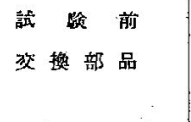 }} & \multirow{3}{*}{\multicolumn{2}{|c|}{$\begin{array}{l}\text { ピストン } \\
\text { ピストンソンダ } \\
\text { コンロッド帅受 }\end{array}$}} & ピストン \\
\hline & & & & ビストンリンク \\
\hline & & & & シリンダーライナー \\
\hline \multicolumn{2}{|c|}{ C.R.C. 試踰名称 } & \multicolumn{2}{|c|}{$-\cdots$} & $\mathrm{L}-1,545$ \\
\hline \multirow{5}{*}{$\begin{array}{l}\text { 試 } \\
\text { 韺 } \\
\text { 項 } \\
\text { 目 }\end{array}$} & リンク噖籍。 & - & 0 & 0 \\
\hline & 湆 性 & .0 & 0 & 0 \\
\hline & 相受能 & 0 & $\therefore$ & - \\
\hline & シリンダー磨被 & $\therefore$ & - & $0^{\circ}$ \\
\hline & 油穴定 性 & 0 & - & - \\
\hline \multirow{3}{*}{ 試 } & 試驗㭙闎 $(\mathrm{Hr})$ & 60 & 100 & 480 \\
\hline & 回枟数 ( $\mathrm{rpm}$ ) & 1840 & 1840 & 1.000 \\
\hline & 慗出力 (BY) & $1 \cdot 86$ & $1 \cdot 86$ & $19: 8$ \\
\hline 䮈 & 冾却液渴. $\left({ }^{\circ} \mathrm{F}\right)$ & 210 & 350 & 177. \\
\hline 㭉 & 油温 $\left({ }^{\circ} \mathrm{F}\right)$ & 280 & 183 & 147 \\
\hline \multirow{3}{*}{ 件 } & 油 聂 & $1 \cdot 50$ & $1 \cdot 53$ & $5 \cdot 00$ \\
\hline & 沘烄贫 & なし & ts & 120㭙間ごと \\
\hline & 油襍 給 & なL & 25特間ごと & 24㭙䦓ごと \\
\hline
\end{tabular}




古 屋和彦

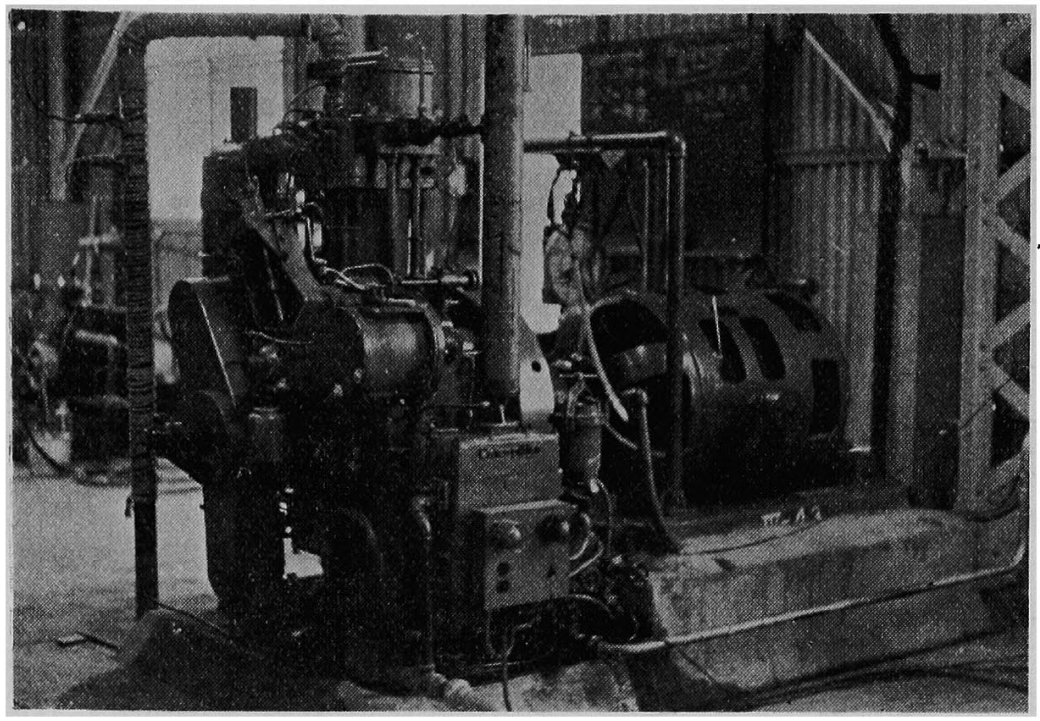

ン油の酸化安定性の評価に 使用されてをが，1954年 の 月以来，乙れ換わる べ CLR oil test engine が実験供されているの で，L-4 エンジンは製作が 中止さ祅ているょらです 当.

(iii) 作動油の剪断安定 度試験，(shear stability test） 加圧した流体飞機 械的仕事をさせるをめの作 動油は，それ㴗求される 性能が多々ので各種の添加 凨を含んでいるが，特に流 体の粘度温度特性を改善す 写真 2 Caterpillar L-1. るため的，高分子物質をる

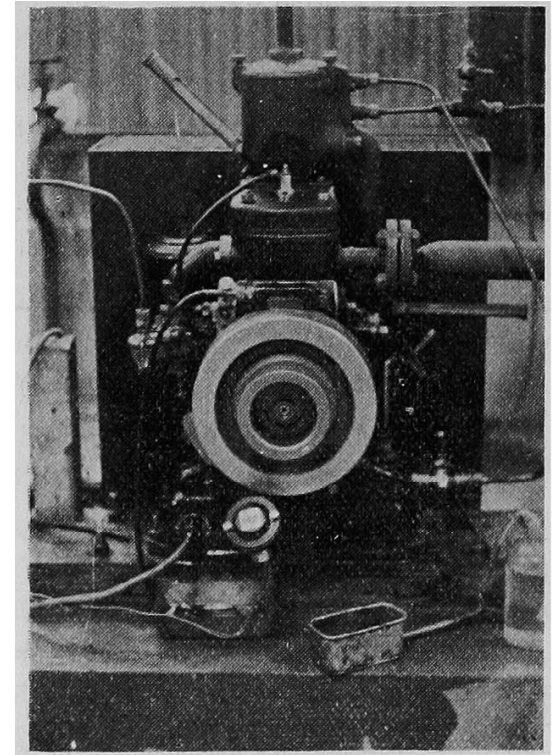

写真 3. Lauson H-2.

にあつてはエンシンンの設計，運転状熊，然料などよ り潤滑油の潤滑性能はんちじるしく影響されるから， 実用実験によつて最終的に評洒されるが，実験室的に ある程度選択するをるに種くの試験エンジンが使用さ れるに至つた。 ここには Caterpillar L-1, Lauson H-2 紹介する，それそれ第 1 表に示す諸元のるのて 所定の方法で運転し, 油の酸化，ピストンの污損，上 ングの膠着, オイルリングの閉塞,聘受の摩耗,エンジ ソ全体の污損なとによりエンシン油を奉験室的に評価 寸るのである. 写真 2 は整社中央研究所のCaterpillar L-1 であり，写真 3 は同所の Lauson H-2 である.

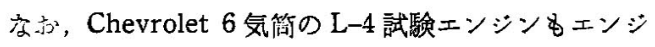

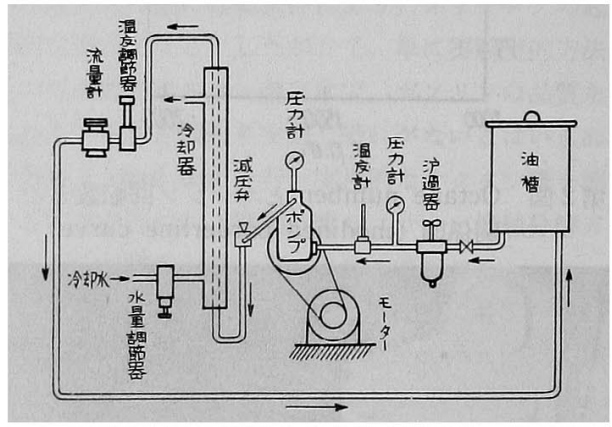

第 3 図前断安定度試験機系統図

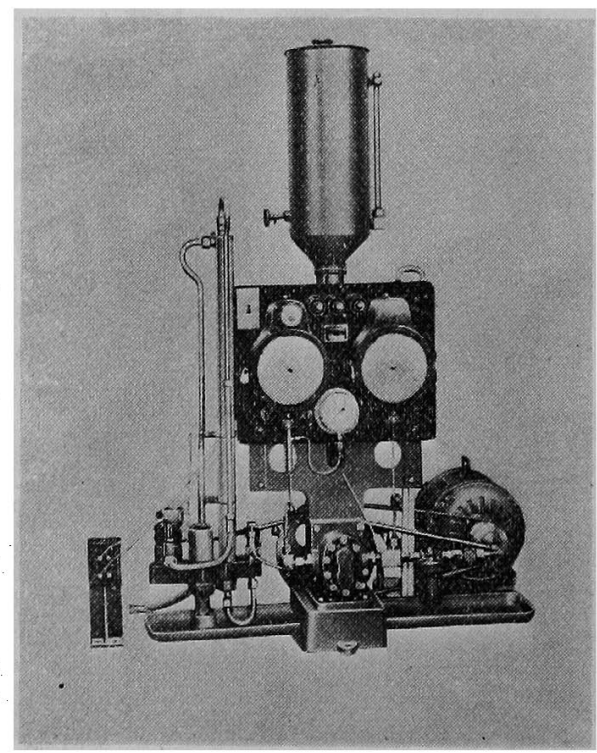

写真 4. 新断安定度試験機

「材籼試験」第 6 巻第 40 号 
粘度指数向上㶡が相当量配合されている非ニュートン 流体が用放れる。したがつて，劕断力が緑り返し作 用すると，使用しそ粘度指数向上剤の種類によつて， その粘度温度関係はらちじるしく变化する，本法はこ の剪断力による流体の性能変化を一定の基萑と此校し， 優劣を判定せんとする試験でる。試験装置の概要は 第 3 図沅示すと扣りであつて，一定量の詿料を一定の 温度で一定流速に保らつつ一定圧力に圧縮し，さらに 减压する操作を一定回数繰り返完させ，その変化を試 験するすのであるが，試験条件は各作動油によつて若 干異なつている。試験後は試料について粘度低下率, 中和価を測定するが，いすれの場合飞す試料が暗色化 したり，添加剂が分離したり，スラッジが生成しては ならない，また，同一試駼機を用的て前断安定度試験

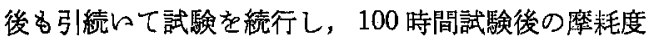
をみる摩耗試験も行われる，写真 4 は慗社中央研究所 の剪断安定度試験機である.

（iv）防錆試験 鉱油には防錆力があるので，防 錆の目的に広く使用されてをてが，あらをに第 2 次世 界大戦の所産として防錆油が登昜した，すなわち，南 方戦域に扣ける高温高湿下の武器の運搬，眝藏並びに 塩水の影響下の運搬, 貯藏淿は在来の単体鉱油では発 錆の防止ができず，困惑した米軍の生み出したすので 少つて，乙れは，薄膜型防錆油，嘍嗼型防錆油，液状 防錆油，反分汸られる。

な叔，第 2 次大戦勃発前化和ける米国のタービン事 故の大多数は発錆によるすのといわれ，防銷剂を添加 した inhibited turbine oil 加使用されるに至つた。 これら防錆油和よびタービン油の防錆力を評価する方 法がことに記す防錆試験で，原理はにすれれ供試油を 洷布しを試験片を所定の条件下にて一定時間処理して 発錆の有無をみるのである.

(a) Humidity cabinế test 現在数種の方法が行われているが， ここには最す広く行われている米 軍規格 JAN-H-792 の方法につ々 て記す。

内径 $70 \times 70 \times 70 \mathrm{~cm}$ の保温さ れた金属製 cabinet 中凡底面加 $20 \mathrm{~cm}$ の高さまで蒸溜水を湍たす。 cabinet 底部々秦楛の air diffuser を備え，吹き辽まれた空気はこれ によつて小泡となり，水磨中を上

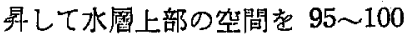
$\%$ \%相対湿度に保つ。この空間に 油を笁布しを試験片が吊されてあ り，稔吊台は 1 分間約 1 回転の速 昭和32年 1 月

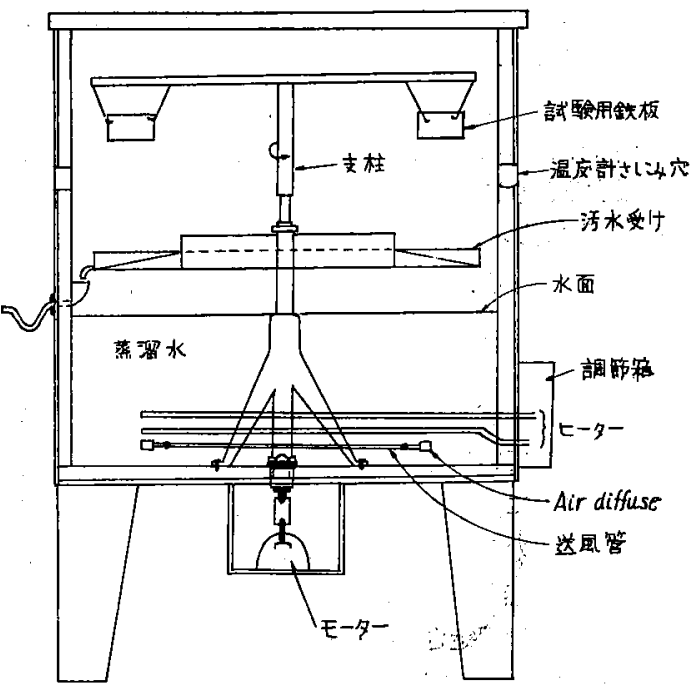

第4図 Humidity cabinet.

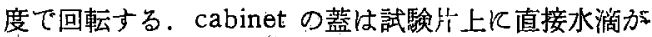

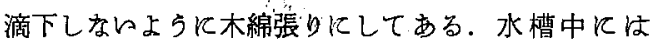
500 ワットのヒーターが 2 筒備克られ，試片面上の空 気温度を $49 \pm 1^{\circ} \mathrm{C}$ 飞保つよう飞温度調節器がつけてあ る. cabinet 中の蒸溜水注常炕一定レベルを保つ上う 飞補給される。試験片は $4^{\prime \prime} \times 2^{\prime \prime} \times 1 / 8^{\prime \prime}$ で材質壮各防 錆油の規格に応じをるのが使用されるが，普通は Federal Spec. QQ-S-636 の低炭素鋼が用らられる. 試䮦片の前処理法，鉒油方法は各防銷油飞よつて異な る.第 4 図借造の概要を示す.

(b) Salt spray test ASTM Disignation : B 117-49T孙よび Federal Spec. VV-L-79/e Method 4001.1 亿規定されている.防錆油を惩布しを試験片 に食塩水の噴霧を吹をつけて防錆力をみる方法であ る.

鉄製容器の内面をゴムで内張りし，との内部に食塩 水貯槽，噴霧ノズル，試験片架台を備元，圧縮空気以一

この試験方法は

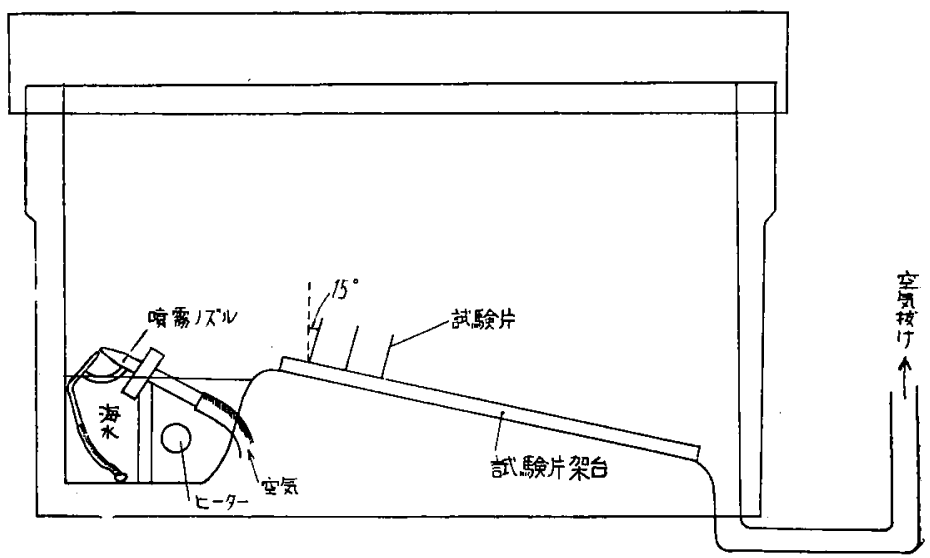

第 5 図 Salt spray. 
よつて食塩水貯梙中の食塩水をノズルから貲霧にして 吹き出させる：試験片は垂直線に対して約 $15^{\circ}$ の角度 をなし, 試験片表面が容器内の嘴蓩の主流に対してな るべく平行になるよらに支える，食塩水濃度は $2 \%$ 使用するように定めているすのが多い，試験温度は92

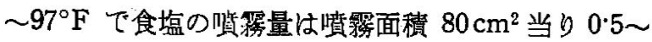
0.3l/hr である. 試験片の材質, 前処理は humidity cabinet の場合と同じである。第 5 図にとの概要を示 す.

（c）タービン油の防錆試験 ASTM : D 665-54 炇規定されているすので，供試油 $300 \mathrm{cc}$ K試験片を浸 濽し，乙れに蒸溜水または人工海水 $30 \mathrm{cc}$ を加え，液 をかきぜかが規定時間 $60^{\circ} \mathrm{C}$ 亿保つた後, 試験片 の発錆の有無を調べ る、試驗片は規定さ れた形状，寸法，組 成の鋼製丸棒で, メ チルメタアクリレー 卜樹脂製の保持器反 ぬじ込み，規定され た形状，寸法の有蓋 ガラス容器中に保持 される。供試液と試 駼片の接触を均一飞 するために，材質， 寸法, 形状の規定さ れた筧抖機を備え， $1000 \pm 50 \mathrm{rpm}$ で回 :転させる、試験前に 試験片は規定された 研糜法によつて前処

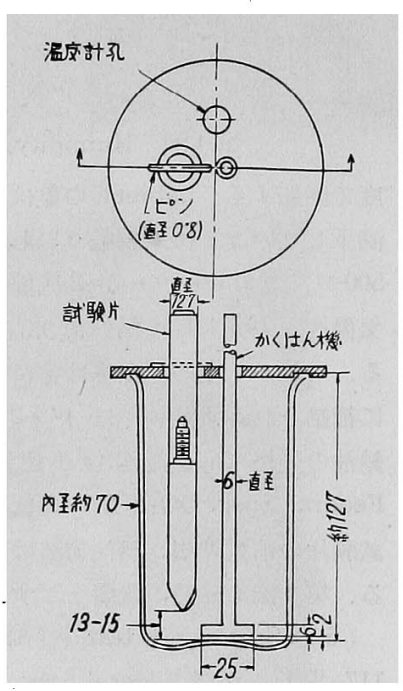

第 6 図 タービン油の 防錆試験機
理される。第 6 図に試驗機の概要を示す。なお，乙の 試験法はある種の作動油の防錆試験にる適用される。

（V）油膜強度試験方法 㵎滑油，殊にギヤー油 の油膜強度あるいは焼付荷重を試験する試みは古くか らなされてをたが, 1930年の初期から多くの試験機が 製作されるに至つた。すなわち, 1931 年沉 General Motors の Almen 試験機, 1932 年に Timken Roller Bearing Co. のティムケン試駼機，1933年には Boerlage そより四球試験機が創案され，ての後も紹介され た試験機の種類は少なくないが，いすれも油膜に充分

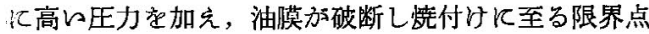
を見出すととを目的としている。 これらのうち代表的 な⿱宀丁口は四球式試験機で，かが国では曾田四球油試験 機，米国扣よび英国ではシェル四球極王潤滑油試験機 (Shell four-ball extreme pressure lubricant tester) が広く使用されている。

（a）曽田四球油試験機 四球試験機は Boerlage
のものから曾田あるいはシェルK至るまで幾つかの種 類があるが, いすれる同一原理に基いていて, 基本的 構造はピラミッド型に積み上げを4簡の同一直径の昋 聑受用鋼球からぬり，4䇫のらち下の 3 簀を固定し， 上の1㯺を下の 3 篾に押し付けながら回転させれぱ, 3 䇧の点接触部がきわ微小な円形珤擦面を形成し て，その間の潤滑油試料に非常に高、王力を加えるこ とがをる。

曾田四球油試駼機は東大曾田教授の考案になるもの で，主要部分は第 7 図に示してあるが，(1)は試験球で 上の 1 䇴は(2)に，下の 3 筒は(3)に固定され，(2)はモ ーターて回転し，(3は試油を入れるカップであり，(4) のピストンを経て油圧で押しあげられて試験球に荷重

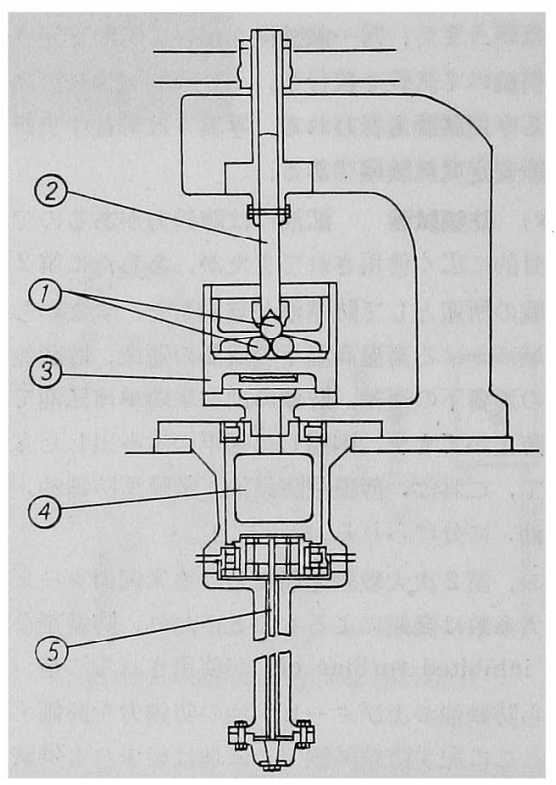

第 7 図 曾田四球油試験機

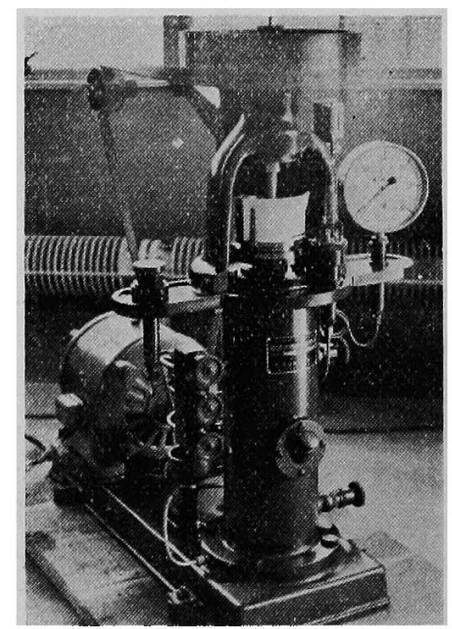

写真 5 . 曾田四球油試験機

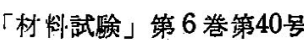


が加兊られる. (5)弾性换れ棒で(2)の回転によつて回

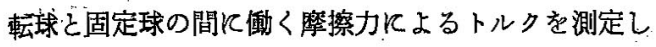
て捤擦係数を算出する。試験方法は試験球をセットし 試油をカ、ソプ満をし，モーターを駆動して回転球を $200 \mathrm{rpm}$ で回転させ，荷重を油压で每分 $0.5 \mathrm{~kg} / \mathrm{cm}^{2}$ の割合で.上年させ焼付けに至る荷重を求める. 写真 5 は慗社中央研究所の同機である。

（b）シエル四球極圧潤滑油試験機シエル四球 圾験機忙米国沉和々て:連邦規格 VV-L-791 など採 用されているもので，主要部分的第 8 図に示すと和り で,曾田試験機と同様に(1)の試験球のうち回転球は 2) の回転帆飞直結し，固定球は(3)のカップ飞セットされ， 荷重は(4)のレバーKよりカップに伝達される。試験球 の間の摩擦力は固定球のカップに取り付けたアームか ら(5)摩摖記録装置に伝充られ，(6)のスプリングと釣 合々，摩擦力の变動は桩大されて(7)の回転ドラム上に

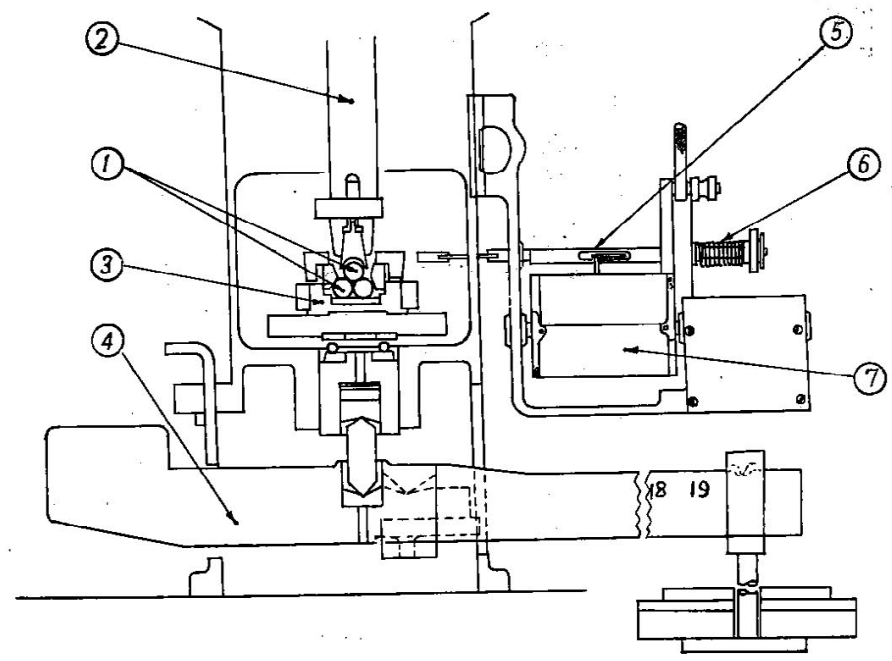

第 8 図 シェル四球極王潤滑油試験機

記録さ礼る。試験方法は組立後，試油をカップ飞満た したのち，所定の荷重をレバーによつて加える．回転 球を $1750 \mathrm{rpm} て ゙$ 回転させ 1 分間後焼付けの有無を調 べる. 各回ととに試験球扣よび試油を交掺して低荷重 から徐々に荷重を增加して暁付けに至るまで測定を繰 b返す. 写真 6 江弊社中央研究所の同機である.

(c) ティムケン試験機 四球試験機と已を比 蔽的広く利用され，米軍規格 AXS-1568なとに採用さ れているもので，回転軸て取り付けられを試験環が支 持台に固定された試験片の上面に接し，との摩擦部に 供試油を滴下しふがら測定を行う。荷重はシェル試験 機之同様にレバーで試験片支持台に加允られる。試験 は試油を試験片の上滴下させ，回転柚を $800 \mathrm{rpm} て$ 回転させながら所定の荷重を加光10分間運転した後， 续付汀有無を調ベ、四球試験機と異なる点はティ

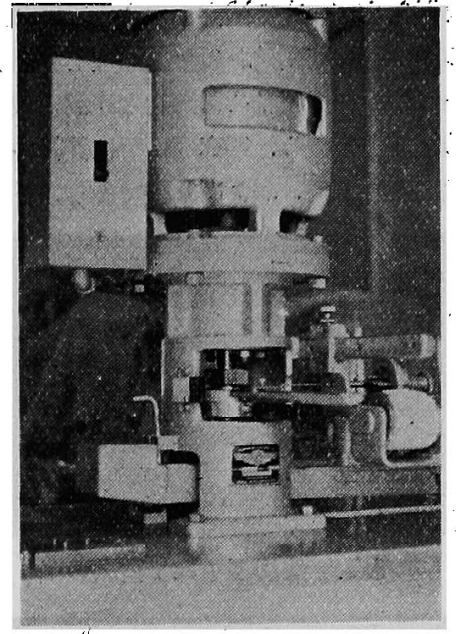

写真 6. シェル四球極王潤滑油試験機

\begin{abstract}
ムケンでは摩擦部が線接触である ことである。
\end{abstract}

（iv） 摩摖係数試験法 動際 擦係数を測定する試験機にT型振 子式試験機があり，潤滑油の境界 潤滑性能を知るため用斿えれて ロる。現在, かが国て広く用いら れているのは曾田教授考案の $\mathrm{T}$ 型 のものである．原理は振子の支点 几榄擦面を設けて, この面を試油 でぬらし，振子の振動の減衰が， この籄所の摩擦抵抗モーメントK よることを利用したものである。 試験機の構造の概要は第 9 図に示 すと扣りで，(1)放円筒とV型㩐 の組合せで，(4)就重鍾，(3)は振子 飞固定しを針で，目盛板(5)によつ て振幅の减少㕝目測する。 (6)劫熱用電熱器で測定温 度を変化させるためのすのである。測定は一定角度よ

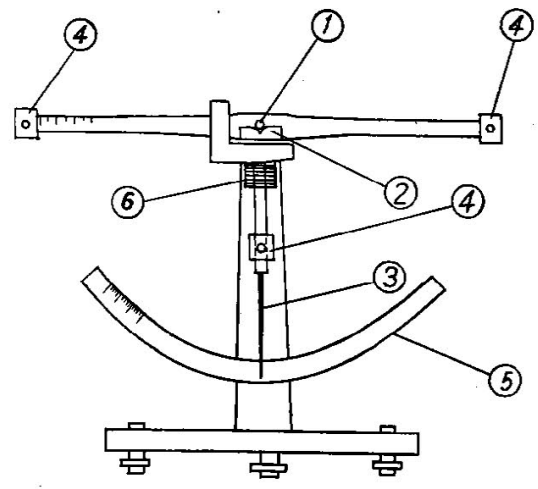

第 9 図 T型振子式試験機 
り振子を振らせ，一定の減衰を示すまで繰り返して， その時の振動数と減衰角加ら祭擦係数它算出する。. 本 機の痤かに摩擦面の組合せを円筒と4個の銅球にした 丁型試験機 II型もある，写真 7，8 は整社中央研究所 の振子式試験機 I 型，および II型である.

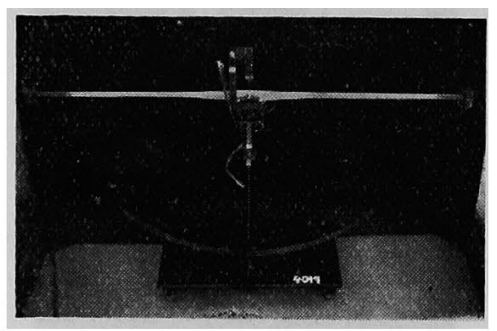

写真 7. T型振子式 I 型試験機

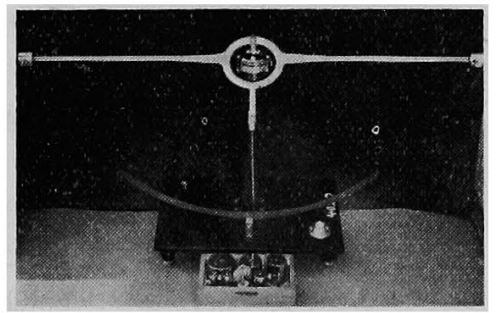

写真 8. $\mathrm{T}$ 型振子式 $\Pi$ 型試歌機

·(vii) 瀾滑油の酸化安定度試験法 酸化安定度と は酸化変質に抵抗する性質で，酸素，樊，水，および 金属の接触作用によつて影響される.

潤滑油の使用寿命の長々とと，すなわち，新油時の 物理的, 化学的性質方使用中に変化しないととはきわ ぬて望をしいことである。潤滑油の酸化安定度は油の 組成，使用条件によつて左右される。乙の使用条件下 に扣ける劣化度定評価する方法かての試験法で，エン シン油, トランス油, ターピン油, 作動油につマて種 々な方法が行われているが, いすれす金属触媒, 酸素 まをは空気の影䇾下に劣化を促進させ，酸化安定度を 評価するのである，各種の方法のうち，とこにはタ一 ビン油の酸化安定度試験法とトランス㴼の JIS C 2320 -1955 亿規定された方法の概要 を記すとととする。

(a) ターピン油の酸化安定 度試験法 ASTM : D 94354 Tに規定されているもので， 添加剂入りタービン油の酸化防 止剤の寿命を測定するのに用ら られる. 所定の形状，寸法，材 質の酸化器中に, 所定組成の銅 線加よ潭気銅線を所定の形状， 寸法に巻き, 容器中の所定位置 亿直く，供試油を所定量触媒上 に注いで試料でぬらす。との酸
化器を $95 \pm 0.2^{\circ} \mathrm{C}$ 飞保ち うるような恒温浴中で所 定の深さに保持す当，次 K, 本酸化器中の所定位 置伀酸素次込管を位置さ せ，一定圧力に調節した 酸絜を流量計を経て吹込 管に通し，その流量か $3 \pm 0 \cdot 5 l / h r$ となるように する. 30分後次蒸溜水 60 cc を酸化器中反添加し, 試験開始時間とする。 か くして所定の試驗行 䅂了後, 供試油の中和 価を湘定するとともに， 触媒，供試油の外観を観 察する。試験は 1000 時 間で中止するとと市

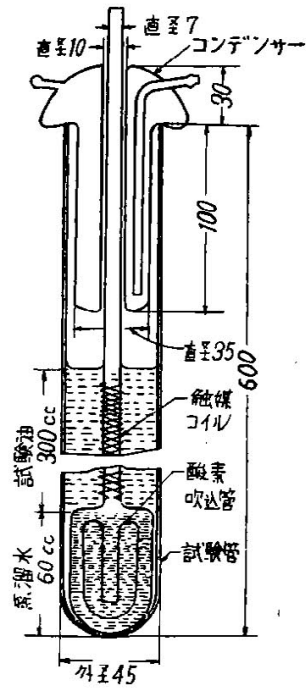

第10図タービン油の 酸化器
り，中和価が $0.25 \sim 2.0$ の一定値に達する時間をみる こともある。触媒於よひ酸化器注試験開始の直前に規 定された方法で前処理する，第10図に酸化器の概要を 示子.

（b）絶緣油の安定度試験方法 JIS C 2320-1955 に規定されている方法で，酸化防止剤を含まないるの に適用される。所定の形状，寸法，材質の容器中に所 定の形状，組成の銅触媒を入れ，さらに供試油 $25 \mathrm{cc}$ を規定された方法によつて採取し, 所定の温度に保 それた恒温浴中の所定位置飞位置させる。次に，所 定濃度の酸素所定の方法によつて，所定量供試油中 に 75 時間通す. 所定時間の酸化を終つを試験容器は 所定の方法によつて暗所に 1 時間放置する.しかる後 に所定の方法て酸化油の全酸価の測定とスラッシの定 量を行う. 試験前飞栻験容器と触媒は所定の前処理を する，第11図に試験装置の概要を示す，な扣，本試験 方法は米国にて行われている sludge accumulation

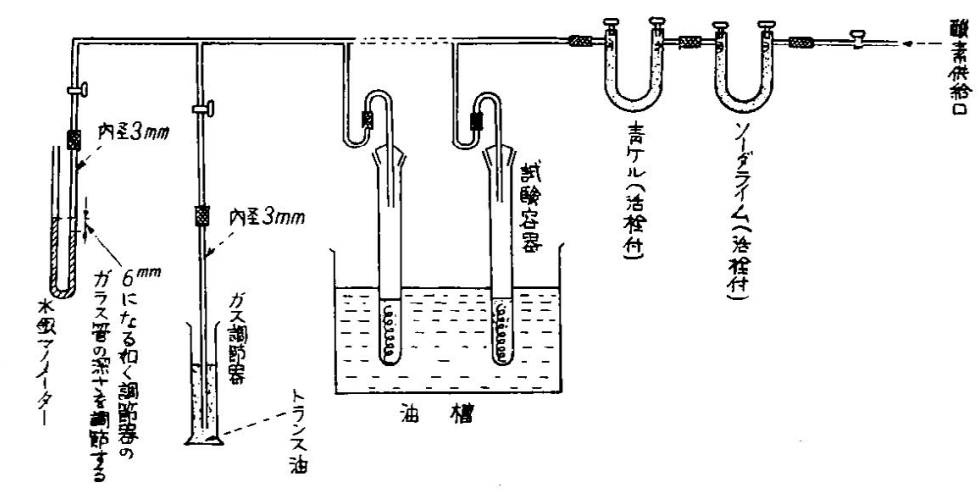

第 11 図 絶縁油の安定度測定試験装置 
test と high pressure oxidation bomb test の中間 を的くが国独自の方法で，3 年以上沉わたつて関保 者が研究協議した結果，決定されたものであり，field performance との関連につレてのデーターがないが有 意義なすのである.

$$
\text { 3. 結言 }
$$

石油製品の使用時に和ける性能を評価せんとする試
験法は，とのはかにす幾多あり，今後とも新しい方法 が生れてくるであろうが，以上は比校的近年提案され 利用されているもの，および古いるのでも近年とみに その利用度の增大したすののらち，代表的のるのを選 で記述したものである。

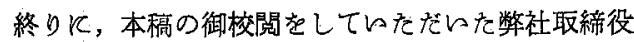
景平一雄博士飞深甚の謝意热表する。

\section{木材建造物の老朽度測定と耐用年限判定法*}

十代田三 郎**

\section{1. 序言}

木造の建築，橋梁，電柱などは，その構法がよくな 的とは $2 \sim 3$ 年化してすて展朽する場合があるが， 逆にその構法がよりと 1000 年以上経過してもな赫使 用火耐完らるすのがある。材の老朽の和すな原因は 菌害と虫害であるが，その老朽の程度は従来は主とし て外観的観察により，まを，その耐用年限は長年月に わたる統計的数字によつて判断されていたが，外観的 観察は主観的なものて観察者の判断てよつて異なり， また，統計的耐用年限判定法は一般的なのであつて， 個々の建造物につ々て適確な判定ができない.

ここでは木材の老朽度の定量的試験法と, 建造物に 対する耐用年限判定法につレて述べようとするすので ある。

木材が豊富にあつた時代に抽々ては，木造建造物は 最も簡易て廉価ぬ構法として広く用いられていたが， 近年，木材の需要籁囲が拡大されるに従に，木材が不 足をきたしている上燃焼しやす的ととと，老朽しや すいことから，建築はもちろん，橋梁，坑木，電柱，

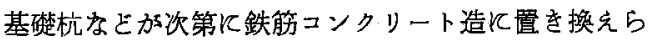

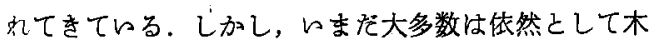
造である.てれら木材建造物の附用年限の延長を泣 るととは木材節約の 1 法である. 以下に和いては，こ の耐用年限の延長法の基礎的研究の一部として，まえ， 木造建造物の耐震耐風的危除を未然に防ぐあ，木材 の老柯度試験法之耐用年限判定法を提案する次第であ る.

\section{2. 木材の菌害と虫害}

木材の老朽の原因の和もなのは菌害と虫害で，そ

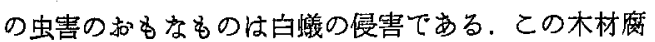

* 原稿受付 昭和31年9月13日

** 早咟田大学理工学部
朽菌と白㠉の繁殖条件が類似しているをめ，一般焜 同されやすいが，前者は植物で後者は動物であるから， まつたく別のすのである。すなわち，菌害は下等寄生 植物の木村腐朽菌が扣のすから分泌する䣼素によつて， 木材の主要成分である絨維素を分解して栄盖素を摂取 するものであるから，年輪の春材と秋材の区別なく溶 解寸るのであり，腐朽部はきわ脆く指で容易にく だくことができる。しかに，白蟻はいらまでもなく 動物であるから，春材の柔加部分を侵蝕して秋材の 硬以部分を残し，被害部の木口を指でさわる己痛く感 方るため容易炕区別がつく、

木材腐朽菌はその種類が多く，その和多をのは口 タグサレタケ、ナミダタケ，カイガラタケ，イチきウ タケ，スエヒロタケ，カワラタケ，クロクモタケ，七 イロタケ，カイメンタケなぞでるが，そのらち最も 被害の大きいのの忙ワタグサレタタの類である。

虫害としては，和もに便木を犯すキクイムシもある

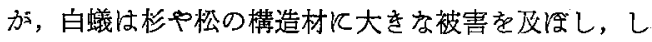
ばしば耐風酎震上危険を招く，との白蟻のうち，和す なものはヤマトシロアリとイエシロアリで，ヤマトシ ロアリは全国的汾分布しているが，東北地方加ら北海 道の上うに寒冷地はその被害は少なく，イエシロフリ は静岡以西で南方の䁔地に向ら活に゙被害が甚大である。

\section{3. 木材の老朽度試験法}

木材の腐朾度を肉眼的観察によつて判断するには， 色が淡谓色加ら褐色飞变化乙，脆くなることを利用す るが，これ恃あくまです定性的で，かつ，腐朽が相当 進行してから初めて認識できるのであつて；鹰朽が初 期，まをは中期に斿りては観察によつては判断が国難 である、その健全部と被害部から試験片を採取して重 量, 強度老測定し，その减少率飞よつて初期腐朽程度 のものす定量的に測定するととがでをる. 